について，何らの義務も課することはない，

(1) 申込必要書類：1. 奨学生願書 (所定用紙), 口. 在学証明書または在職証明書, 八. 高等学校成績証 明書 (助教授・講師・助手は不要), 二. 大学学部成 績証明書, 木，大学院成績証明書, へ. 現在までの 論文, 業績一覧表 (学部・院生は不要), ト. 大学学 部長または指導教官の推薦状, チ。健康診断書（胸 部 X 線, 血圧, 尿, 身長, 体重, 視力), リ。 写真 (願書に張付) $5 \times 5 \mathrm{~cm}$ 上半身正面 脱帽

(2) 願書受付： 7612 京都市伏見区竹田向代町 136, 村田機械（株）総務部人事チーム内, 村田海外留学 奨学会事務局, TEL. 075-672-8117

(3) 受付期間：1. 受付開始 平成 9 年 9 月 1 日 (月), 口. 受付締切 平成 9 年10月 3 日（金）当日 消印有効

（4）注意事項：1．留学希望国は 1 加国に限る。 口. 語学試験は留学希望国の国語で実施.八. 願書の 「留学目的と将来の希望欄」は必ず記入のこと.

\section{（第20回）石本記念デサントスポーツ科学 振興財団学術研究募集}

スポーツ関連科学に関する学術の研究を奨励援助し, 健全な体育, スポーツの振興と発展に寄与するため, 第 20 回スポーツ科学技術研究公募を実施する.

第 1 部はより時代を先き取りした研究を奖励するため に当財団の定めた課題学術研究への助成, 第 2 部は自由 課題による学術研究への助成となる.

〔主〔催〕財団法人 石本記念デサントスポーツ科学 振興財団

\section{〔応募資格〕}

(1) 体育学, 健康科学, 人間工学, 被服科学, 運動施 設工学等健康の増進と体力の向上に関する学術, およびその他スポーツ振興に寄与する学術研究に 関する講座を持った大学およびこれに準ずる研究 機関に所属する個人またはグループ.

(2) 高校生から幼児までの教育機関に奉職しており, (1)に前述した分野で研究または調查活動を積極的 に行っている個人またはグループ.

この場合, 運動生理学的研究でなくとも, あく まで教育現場における身近なテーマで,すぐにも 役立つ研究テーマを求めている.

ただし, 研究報告等に不慣れの人は, 報告書作成に

習熟した人を共同研究者に加えて申請のこと.

〔内容〕

第 1 部 課題学術研究 本年度テーマ「トップアスリートを支えるス ポーツ科学」

第 2 部 自由課題学術研究

従来どおり本財団の主旨に添ったものであ
り, 申請者がこれまで行ってきた研究を助成す ることによって, 調查・研究の発展・充実が期 待されるものであること.

\section{〔応募方法]}

応募者は, 所定の申請用紙に研究テーマ, 第 1 部, 第 2 部の区分, 目的, 内容および期待される成果などを簡 潔に書き, 平成 9 年12月10日（当日消印有効）までに下 記宛提出のこと.

（応募者多数の場合, 申請者はコピーであ可, ただしコ ピー使用の場合, 第20回申請書をコピーのこと, 他の方 法による作表および前回までの用紙は使用しないこと） 〔助成金の交付〕

第 1 部「課題学術研究」 1 件100 200万円（件数 1 2 件)

第 2 部「自由課題学術研究」研究内容に応じ, 最優秀 入選 100 万円, 優秀入選50万円, 入選40万円, 佳 作入選 30 万円（件数約 25 件）

〔応募書類送付先資料の請求および問い合わせ〕

財団法人 石本記念デサントスポーツ科学振興財団編 集室（テ546 大阪市東住吉区今川 5-1-32, 侏デサント商 品研究室内, TEL. 06-705-1638, FAX. 06-704-7707

\section{人事}

\section{村田機械}

社長 村田純一, 副社長 岡本喜市, 専務取締役 松井 勇, 藤本貞夫, 常務取締役 林 孝雄, 村田大介, 取締 役 貝原 明, 山本雅和, 田中良治, 松田亘弘, 荒牧三 郎, 藤田正武, 二谷明紀, 進藤 昇, 森橋俊文, 小杉敏 人, 西谷勇次郎, 渡部崇男, 村田洋介, 監査役 上羽達 雄, 上野勝彦, 楠 昌治.

\section{名称変更}

「富山県工業技術センター㵶維研究所」は 7 月 1 日付 けで, 「生活工学研究所」と名称を变更した. 所在地も富 山県東砺波郡福野町岩武新 35-1 に変更となる。なお, TEL. 0763-22-2141, FAX. 0763-22-4604は従来通り.

\section{訂正}

本誌 8 月号 (Vol. 50, No. 8) に次の誤りがありました ので訂正します.

・70頁「スパンデックス糸の空気抗力に及ぼす糸断面形 状の影響」の表示頁 P216〜P223は T216〜T223に.

•63頁「インターレース系の摩擦交絡強度」の T213の Fig. 5, (b) Effect of static Tension, (c) Effect of friction angle $は$ (b) Effect of friction angle,

(c) Effect of static tension $に$.

・16頁「乾式短織維不織布」の著者略歴,「敦賀工場」は 「滋賀工場」に. 